\title{
Budidaya Kopi Rakyat dengan Pengelolaan Bahan Organik Mengurangi Emisi Gas Rumah Kaca dan Cadangan Karbon
}

\author{
Hesti Yulianingrum ${ }^{1}$, Ika Ferry Yunianti ${ }^{1}$, Maria Angelina Nai Ulu² \\ ${ }^{1}$ Balai Penelitian Lingkungan Pertanian, Jalan Raya Jakenan Jaken KM 5 Pati, Jawa Tengah Indonesia; e-mail: \\ hestiyulianingrum@gmail.com \\ 2Dinas Pertanian Provinsi Nusa Tenggara Timur, Jalan Polisi Militer 7A Kupang Nusa Tenggara Timur Indonesia
}

\begin{abstract}
ABSTRAK
Peningkatan konsentrasi gas rumah kaca (GRK) akibat dari kegiatan pertanian akan menyebabkan perubahan iklim. Dampak perubahan iklim akan mengancam produktivitas tanaman kopi. Upaya mitigasi GRK perlu dilakukan untuk mencegah penuruan produktvitas kopi. Tujuan penelitian ini adalah untuk mengetahui emisi GRK dan cadangan karbon dari perbedaan jenis pupuk yang diberikan (sistem organik dan konvensional) di perkebunan kopi rakyat di Provinsi Nusa Tenggara Timur. Penelitian dilaksanakan pada lahan perkebunan kopi rakyat di Desa Radabata, Kecamatan Golewa, Kabupaten Ngada, Provinsi Nusa Tenggara Timur (NTT). Kegiatan penelitian dilaksanakan pada dua lokasi dengan sistem budidaya konvensional (tanpa penambahan bahan organik) dan organik (penambahan bahan organik). Kegiatan yang dilakukan adalah pengukuran gas rumah kaca (GRK) serta cadangan karbon. PengukuranGRK menggunakan metode sungkup tertutup dengan 4 titik pengambilan sampel. Perhitungan cadangan karbon dengan pengambilan sampel biomassa kering denga metode RaCSA (Rapid Carbon Stock's Assesment). Hasil penelitian menunjukkan perkebunan kopi mampu menurunkan GWP sebesar 24,77 \% dibandingkan pada sistem konvensional. Perkebunan kopi rakyat dengan sistem konvensional menghasilkan cadangan karbon dan serapan karbon yang lebih besar dibandingkan dengan sistem organik. Keragaman jenis tanaman penaung, umur tanaman dan sistem budidaya sangat mempengaruh cadangan karbon yang dihasilkan pada suatu lahan. Pengelolaan perkebunan secara organik dengan tanaman tahunan sebagai penaung (Agrogorestri) merupakan kegiatan ramah lingkungan sebagai upaya mitigasi gas rumah kaca.
\end{abstract}

Kata kunci: Emisi GRK, Tanaman kopi, Cadanngan karbon, Mitigasi, Agroforestri

\begin{abstract}
Increasing the concentration of greenhouse gases (GHG) due to agricultural activities will cause climate change. The impact of climate change will threaten the productivity of coffee plants. GHG mitigation efforts need to be carried out to prevent decline in coffee productivity. The aim is to determine GHG emissions and carbon stocks from the different types of fertilizers given (organic and conventional systems) in smallholder coffee plantations in the East Nusa Tenggara Province. The study was carried out on smallholder coffee plantations in Radabata Village, Golewa District, Ngada Regency, East Nusa Tenggara Province (NTT). Research activities were carried out in two locations with conventional cultivation systems (without organic materials) and organic (organic matter amendmend). The activities carried out are measurements of greenhouse gases (GHG) and carbon stocks. Measurement of GRK uses a closed chamber method with 4 sampling points. Calculation of carbon stocks with dry biomass sampling with the RaCSA (Rapid Carbon Stock Assessment) method. The results showed that coffee plantations were ablle to reduce GWP $24,77 \%$ compared to conventional system. Smallholder coffee plantation with convensional system produce greater carbon stock dan carbon uptake compared to organic system. Diversity of shade plan, age of plants and cultivaton system greatly affect the carbon stock produced on a land. Organic plantation management with annual crops as shade (Agrogorestry) is an environmentally friendly activity as an effort to mitigate greenhouse gases.
\end{abstract}

Keywords: GHG emission, Coffee plant, Carbon stock, Mitigation, Agroforestry

Citation: Yulianingrum, H., Yunianti, I.F.,dan Ulu M.A.N. (2020). Budidaya Kopi Rakyat dengan Pengelolaan Bahan Organik Mengurangi Emisi Gas Rumah Kaca dan Cadangan Karbon. Jurnal Ilmu Lingkungan, 18(1),97-106, doi:10.14710/jil.18.1.97-106

\section{Pendahuluan}

Peningkatan konsentrasi gas rumah kaca (GRK) akibat dari kegiatan antropogenik dan non antropogenik akan menyebabkan perubahan iklim. Dampak perubahan iklim akan mengancam produktivitas tanaman kopi. IPCC (2014) menyatakan pada akhir abad 21 diperkirakan kenaikan suhu udara 97 akan mencapai $2^{\circ} \mathrm{C}$ apabila tidak dilakukan kegiatan mitigasi. Akibat dari peningkatan suhu tersebut menyebabkan kejadian iklim yang ekstrim (kemarau panjang, curah hujan tinggi, angin kencang, naiknya permukaan air laut). Kemarau panjang akibat El nino dapat mengakibatkan penurunan produksi kopi sebanyak $10 \%$, sebaliknya curah hujan yang tinggi 
akibat La nina dapat menurunkan produksi kopi hingga 80\% (Syakir dan Surmaini, 2017). Selain itu, perubahan iklim dapat mempengaruhi dinamika dan status populasi hama yang dapat mengancam produksi kopi (Bale et al., 2002; Jaramillo et al., 2011; Widayat et al., 2015; Groenen, 2018). Menurut Cerdan et al. (2012), sebanyak 37\% petani merasakan perubahan iklim akan menjadi masalah mendatang di perkebunan kopi. Beberapa petani merasakan dampak perubahan iklim dengan berubahnya waktu berbunga tanaman kopi.

Tanaman kopi merupakan salah satu komoditas utama perkebunan yang menyumbang devisa negara. Pada tahun 2016 kopi menempati posisi ke 4 komoditas perkebunan yang di ekspor ke luar negeri. Perkebunan kopi tersebar di seluruh Indonesia, propinsi Nusa Tenggara Timur (NTT) menempati urutan ke 8 yang memiliki areal perkebuan kopi yang cukup luas di Indonesia. Di provinsi NTT luas areal perkebunan kopi mencapai 64.716 ha, dengan produksi kopi sebesar 21.079 ton (Pusdatin, 2017). Pada tahun 2019, Kementerian Pertanian mentargetkan produksi kopi 0,79 juta ton. Namun, selama periode 1970-2015 tidak terjadi kenaikan produksi kopi yang signifikan (Kementan, 2015). Permintaan kopi yang meningkat, khususnya kopi arabika tidak dapat terpenuhi karena terbatasnya area pertanaman kopi serta produksi yang rendah yang disebabkan oleh perubahan iklim.

Budidaya kopi sangat rentan terhadap perubahan iklim karena memiliki lingkungan tumbuh yang sempit. Terjadinya perubahan iklim dapat mengurangi area produksi kopi mencapai 50\% (Bisang et al., 2016). Sebesar 40,1\% variasi terhadap produktivitas kopi robusta di Malang dipengaruhi suhu (Prasetyo et al, 2017). Pada tahun 2050 beberapa negara akan mengalami penurunan area perkebunan kopi sebanyak $40-50 \%$ akibat peningkatan suhu. Perubahan pola hujan, suhu, angin serta cuaca ekstrem lainnya memberi dampak pada kualitas dan produktivitas kopi (UNDP, 2005; Fain et al., 2017; Groenen, 2018).

Produksi kopi sangat dipengaruhi oleh iklim, namun kopi juga sebagai kontributor perubahan iklim dari gas rumah kaca yang dipancarkan. Sumber emisi GRK utama dalam budidaya kopi sebanyak 94\% adalah penggunaan input organik dan anorganik (Maina et al, 2015). Pertanian di lahan kopi menyumbang gas $\mathrm{CO}_{2}$ dan $\mathrm{N}_{2} \mathrm{O}$. Karbondioksida $\left(\mathrm{CO}_{2}\right)$ dari pertanian dihasilkan melalui kegiatan konversi lahan, pengelolaan tanah. Gas N20 dari pertanian terkait dengan penggunaan pupuk (Sevenster and Verhagen, 2010). Manajeman kegiatan budidaya kopi memberi pengaruh terhadap emisi yang dikeluarkan tanaman. Penggunaan bahan organik, sistem budidaya monokultur/tumpang sari, kandungan air tanah, dan perubahan daya guna lahan dari hutan ke lahan pertanian memberi pengaruh terhadap emisi yang dikeluarkan (Verhot et al., 2006).

Dampak perubahan iklim pada perkebunan kopi dapat diantisipasi dengan teknik budidaya tanaman yang baik (Prasetyo et al, 2017). Penanaman tanaman hutan atau tanaman perkebunan memiliki potensi untuk berkontribusi dalam kegiatan mitigasi dari akumulasi emisi GRK yang dihasilkan karena cenderung lebih tinggi serapan C (Houghton et al.,1993; IPCC, 2000). Penananam jenis leguminose di antara tanaman perkebunan mempunyai peranan penting dalam memfiksasi N. Penerapan sistem tersebut dapat mengurangi sumbangan emisi GRK ke atmosfer.

Sumber utama emisi GRK dari budidaya kopi berasal dari pengelolaan pupuk. Emisi GRK yang disebabkan oleh pengelolaan pupuk sebesar 96\% (Rachawat et al, 2015). Sebanyak 84,3\% dari total emisi berasal dari hilangnya karbon yang berasal dari bahan organik tanah, bahan organik penggabungan dan dekomposisi serasah daun kopi adalah 84,3\% ,dan sisanya 15,7\% dihasilkan dari emisi dari pemupukan nitrogen (Jaramillo et al, 2017). Penggunaan pupuk organik dapat memberi dampak positif terhadap penurunan emisi GRK. (Graham et al, 2017). Pengembangan budidaya kopi secara organik sudah mulai dilakukan banyak di Indonesia. Informasi atau penelitian emisi GRK serta cadangan karbon belum banyak tersedia sehingga perlu informasi dan penelitian mengenai emisi GRK dari pengelolaan lahan secara organik dan anorganik di Indonesia. Tujuan dari kegiatan ini adalah untuk mengetahui emisi GRK dan cadangan karbon dari perbedaan jenis pupuk yang diberikan (sistem organik dan konvensional) di perkebunan kopi rakyat di Provinsi Nusa Tenggara Timur.

\section{Bahan dan Metode}

\subsection{Lokasi penelitian}

Penelitian dilaksanakan pada lahan perkebunan kopi rakyat di Desa Radabata, Kecamatan Golewa, Kabupaten Ngada, Provinsi Nusa Tenggara Timur (NTT). Perkebunan kopi ini berada pada ketinggian sekitar 1.000-1.550 mdpl dengan curah hujan sekitar $2.500 \mathrm{~mm} /$ tahun. Lokasi penelitian terletak pada 2 tipe penggunaan lahan. Tipe lahan dengan sistem organik berumur 6 tahun, dan tipe penggunaan lahan lainnya secara konvensional dengan umur 15 tahun. Kebun bercampur dengan tanaman tahunan (Sengon dan Ampupu) dan tanaman berumur pendek (pisang). Jenis kopi yang ditanam adalah arabika. Lokasi juga dominasi dengan gulma berdaun lebar. 


\subsection{Rancangan perlakuan}

Kegiatan penelitian dilaksanakan pada dua lokasi dengan sistem budidaya yang berbeda. Sistem budidaya yang diterapkan konvensional (tanpa penambahan bahan organik) dan organik (penambahan bahan organik). Kegiatan pengambilan data dengan pengambilan sampel gas pada 2 sistem budidaya dengan 4 titik pengulangan. Pengambilan sampel gas bertujuan untuk melihat emisi gas rumah kaca yang dihasilkan dari 2 sistem budidaya berbeda. Selain itu juga dilakukan pengukuran cadangan karbon dengan mengumpulkan sampel biomassa bawah, seresah dan ranting serta biomassa pohon. Pengambilan data untuk pengukuran cadangan karbon dengan mengambil sampel dengan ukuran plot tertentu. Pengambilan sampel plot untuk mengukur cadangan karbon pada biomassa bawah, seresah dan ranting diulang sebanyak 3 kali.

\subsection{Pengukuran emisi GRK}

Pengambilan sampel gas rumah kaca $\mathrm{CO}_{2}$ dan $\mathrm{N}_{2} \mathrm{O}$ dilaksanakan sebanyak 2 kali pada tanggal 25 Oktober 2018 dan 1 November 2018.Waktu pengambilan contoh gas dilakukan pada pagi $(07.00$ WITA) dan siang (13.00 WITA). Pengambilan contoh gas $\mathrm{CO}_{2}$ dan $\mathrm{N}_{2} \mathrm{O}$ dilakukan di empat titik sampling pada jarak $40 \mathrm{~m}$ dengan metode sungkup tertutup (close chamber) (Minamikawa et al, 2015). Peralatan yang digunakan yang digunakan untuk pengambilan sampel gas antara lain penampang ukuran $43 \times 23 \mathrm{~cm}$ dan sungkup ukuran $40 \times 20 \times 30 \mathrm{~cm}$, termometer, jarum suntik (syringe), dan vial.

Penampang dipasang satu hari sebelum dilakukan pengambilan contoh gas. Penampang dipasang rata di atas permukaan tanah. Sungkup dipasang diatas penampang yang sudah diberi air agar tidak mengalami kebocoran. Termometer dipasang pada pada lubang bagian atas sungkup. Penutup karet (septum) diletakkan pada lubang pengambil contoh gas. Septum dipasang 2-3 menit setelah pemasangan sungkup di penampang agar udara dalam sungkup stabil. Pengambilan sampel gas menggunakan syringe ukuran $20 \mathrm{ml}$ sebanyak 5 kali dengan interval waktu $10,20,30,40$ dan 50 menit. Sampel gas yang telah diambil dengan syringe segera dimasukkan ke dalam vial. Setiap kali melakukan pengambilan contoh gas dilakukan pencatatan ketinggian air dari tanah (headspace) serta perubahan suhu di dalam sungkup. Contoh gas dibawa ke laboratorium GRK untuk dianalisis gas $\mathrm{CO}_{2}$ dan $\mathrm{N}_{2} \mathrm{O}$. Analisis contoh gas menggunakan alat Gas Chromatography (GC) Shimadzu 14A yang dilengkapi dengan TCD (Thermal Conductivity Detector) untuk mendeteksi gas $\mathrm{CO}_{2}$ dan ECD (Electron Capture Detector) untuk mendeteksi gas $\mathrm{N}_{2} \mathrm{O}$. Pengukuran fluks menggunakan rumus berdasarkan IAEA (1992) :

$$
\mathrm{E}=\frac{\mathrm{dc}}{\mathrm{dt}} \times \frac{\mathrm{Vch}}{\mathrm{Ach}} \times \frac{\mathrm{mW}}{\mathrm{mV}} \times \frac{273,2}{273,2+\mathrm{T}}
$$

Dimana :

$\begin{array}{ll}\mathrm{E} & : \text { Emisi gas } \mathrm{CO}_{2} \text { dan } \mathrm{N}_{2} \mathrm{O}\left(\mathrm{mg} / \mathrm{m}^{2} / \text { hari }\right)\left(\mathrm{CO}_{2}\right. \\ & \left.\text { and } \mathrm{N}_{2} \mathrm{O} \text { emission }\left(\mathrm{mg} / \mathrm{m}^{2} / \text { day }\right)\right) \\ \mathrm{dc} / \mathrm{dt} \quad: & \text { Perbedaan }\left[\mathrm{CO}_{2} \text { dan } \mathrm{N}_{2} \mathrm{O}\right] \text { per waktu } \\ & \text { (ppm/menit) } \\ \mathrm{Vch} \quad & : \text { Volume boks }\left(\mathrm{m}^{3}\right) \\ \mathrm{Ach} & : \text { Luas boks }\left(\mathrm{m}^{2}\right) \\ \mathrm{mW} & : \text { Berat molekul } \mathrm{CO}_{2}, \mathrm{~N}_{2} \mathrm{O}(\mathrm{g}) \\ \mathrm{mV} & : \text { Tetapan volume molekul }(22,41 \mathrm{l}) \\ \mathrm{T} & : \text { Suhu rata-rata selama pengambilan sampel } \\ & \left({ }^{\circ} \mathrm{C}\right) ; \text { Nilai } 273,2: \text { Tetapan suhu Kelvin }\end{array}$

\subsection{Pengukuran cadangan karbon (C-stok)}

Pengukuran cadangan karbon diatas tanah meliputi karbon yang tersimpan dalam biomassa pohon, tumbuhan bawah (gulma), seresah dan ranting yang ada dipermukaan tanah. Pengukuran cadangan karbon pada pohon kopi dilakukan dengan metode RaCSA (Rapid Carbon Stock's Assesment). Metode yang dikembangkan oleh ICRAF (International Center for Reseach in Agroforestry) dengan mengukur berat kering biomassa di atas permukaan tanah dalam petak berukuran (Hairiah dan Rahayu, 2007). Ukuran petak dimodifikasi menjadi $10 \times 4 \mathrm{~m}$.

Pengukuran cadangan karbon dilakukan secara destruktif dan non destruktif. Pengukuran cadangan karbon secara destruktif dilakukan pada biomassa di atas permukaan tanah dengan merusak biomassa (destruktif), bobot basah dan bobot kering biomassa ditimbang serta kandungan karbon dianalisa setiap bagian tanaman. Cadangan karbon juga dihitung untuk biomassa bawah (understorey) dan seresah (nekromas non kayu). Pehitungan cadangan karbon menggunakan rumus :

Cadangan karbon $=$ Berat Kering biomass $\mathrm{x} \% \mathrm{C}$ Organik tanaman

Pengukuran cadangan karbon juga dilakukan dengan cara tanpa merusak biomasa tanaman (non destructive), yaitu dengan cara mengukur keliling dan tinggi contoh tanaman, mengidentifikasi jenis tanaman, kemudian dihitung cadangan karbon dengan menggunaan persamaan tertentu (allometrik) (Tabel 1). Pengukuran cadangan karbon dilakukan dalam beberapa tahapan sebagai berikut plot contoh untuk pengukuran ditentukan, pengukuran biomassa tanaman (destruktif dan non destrucktif), nekromas, serta persentase kandungan karbon tanaman dan berat kering tanaman. Pengukuran estimasi kandungan karbon pada suatu lahan. Skema contoh pengukuran cadangan karbon terdapat pada Gambar 1. 
Tabel 1. Estimasi Biomassa pohon dengan persamaan alometrik (Hairiah et al., 2011)

\begin{tabular}{|c|c|}
\hline Jenis Pohon & Estimasi Biomasa pohon (kg/pohon) \\
\hline Pohon bercabang & $\mathrm{BK}=0,11 \rho \mathrm{D}^{2,62}$ \\
\hline Pohon tidak bercabang & $\mathrm{BK}=\pi \rho \mathrm{H}^{*} \mathrm{D}^{2} / 40$ \\
\hline Kopi pangkas & $\mathrm{BK}=0,281 \mathrm{D}^{2,06}$ \\
\hline Pisang & $\mathrm{BK}=0,030 \mathrm{D}^{2,13}$ \\
\hline Bambu & $\mathrm{BK}=0,031 \mathrm{D}^{2,28}$ \\
\hline Sengon & $\mathrm{BK}=0,0272 \mathrm{D}^{2,831}$ \\
\hline Pinus & $\mathrm{BK}=0,0417 \mathrm{D}^{2,6576}$ \\
\hline Kelapa sawit & $\mathrm{BK}=\left(0,0976 \times \mathrm{H}^{* *}\right)+0,0706$ \\
\hline
\end{tabular}

Keterangan: BK: berat kering (g); D: diameter pohon (cm); H*: tinggi pohon (cm); H**: tinggi pohon (m); $\rho$ : berat jenis kayu $\left(\mathrm{gr} \mathrm{cm}^{-3}\right)$; Diameter $=$ Keliling $/ 3,14$

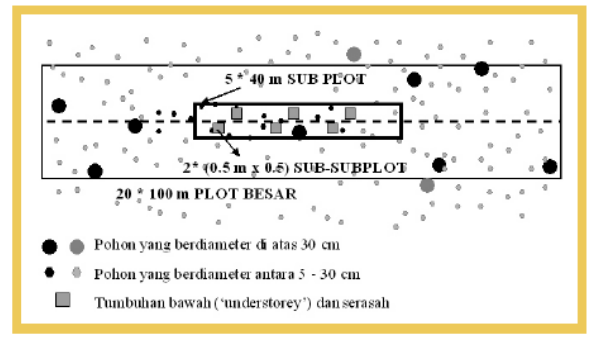

Gambar 1. Contoh plot pengukuran (Hairiah dan Rahayu, 2007)

\subsection{Pengukuran biomassa tanaman}

Pengukuran biomassa tanaman dilakukan dengan mencatat semua jenis pohon serta keliling pohon yang masuk dalam sub plot pada blangko pengamatan. Apabila terdapat pohon yang berdiameter $>30 \mathrm{~cm}$ atau keliling $>94 \mathrm{~cm}$ maka dibuat plot besar. Diameter of breast height (dbh) untuk semua pohon dengan diameter $>30 \mathrm{~cm}$ diukur (Gambar 1). Nama semua pohon yang berdiameter > $30 \mathrm{~cm}$ dicatat.

\subsection{Pengukuran tanaman bawah (understorey)}

Tanaman yang memiliki diameter $<5 \mathrm{~cm}$ yang berada di dalam SUB SUB PLOT ( 6 contoh)(Gambar 1) diambil contoh tanamannya dan dimasukkan kedalam kantong kertas. Berat basah dari tanaman ditimbang (daun dan batang dipisahkan). Sub contoh tanaman dari masing-masing biomasa daun, batang diambil sekitar 100-300 gr lalu dikeringkan untuk dianalisis persen kandungan $\mathrm{C}$ tanaman. Berat Kering biomassa dan persentase karbon dalam tanaman dicatat.

\subsection{Pengukuran nekromas/seresah tanaman}

Serasah yang terdapat di dalam SUB SUB PLOT (6 contoh) diambil dan dimasukkan ke dalam kantong kertas. Berat basah serasah ditimbang. Sub contoh serasah dari masing-masing SUB SUB PLOT diambil 100-300 gram lalu dikeringkan untuk dianalisis persen kandungan $C$ tanaman. Berat kering biomassa dan persen karbon tanamannya dicatat.

\section{Hasil dan Pembahasan}

3.1. Emisi GRK dari lahan perkebunan kopi rakyat Hasil pengukuran emisi gas rumah kaca (GRK) harian di perkebunan kopi rakyat pada di sistem pertanian organik menghasilkan nilai fluks $\mathrm{N}_{2} \mathrm{O}$ rata rata 0,561 $\mathrm{mg} / \mathrm{m}^{2} /$ hari dan fluks $\mathrm{CO}_{2} 5.826 \mathrm{mg} / \mathrm{m}^{2} /$ hari (Tabel 2). Hasil perhitungan emisi gas $\mathrm{N}_{2} \mathrm{O}$ dari lahan perkebunan dengan sistem organik sebesar 2,05 $\mathrm{kg} / \mathrm{ha} /$ tahun (Tabel 3) atau setara $611 \mathrm{~kg}$ CO2e/ha/tahun. Besaran emisi tersebut di NTT lebih kecil dibandingkan emisi pada perkebunan kopi rakyat di Nusa Tenggara Barat (NTB). Menurut Pramono dan Sadmaka (2018), emisi $\mathrm{N}_{2} \mathrm{O}$ dari perkebunan kopi rakyat di NTB sebesar 2,29 kg N2O-N/ha/tahun atau sebesar $1.073 \mathrm{~kg} \mathrm{CO2-e/ha/tahun.}$

Tabel 2. Fluks harian $\mathrm{N}_{2} \mathrm{O}$ dan $\mathrm{CO}_{2}$ dari 2 sistem budidaya pada perkebunan kopi rakyat di NTT.

\begin{tabular}{|c|c|c|c|c|c|c|}
\hline \multicolumn{7}{|c|}{ Fluks $\mathrm{N}_{2} \mathrm{O}\left(\mathrm{mg} / \mathrm{m}^{2} /\right.$ hari) } \\
\hline \multirow{3}{*}{ Waktu } & \multicolumn{3}{|c|}{ Organik } & \multicolumn{3}{|c|}{ Konvensional } \\
\hline & \multicolumn{2}{|c|}{ Sampling } & \multirow{2}{*}{ Rata-Rata } & \multicolumn{2}{|c|}{ Sampling } & \multirow{2}{*}{ Rata-Rata } \\
\hline & 1 & 2 & & 1 & 2 & \\
\hline Pagi & 0,555 & 0,668 & 0,612 & 0,504 & 0,563 & 0,533 \\
\hline Siang & 0,448 & 0,570 & 0,510 & 0,751 & 0,535 & 0,643 \\
\hline Rata Rata & & & 0,561 & & & 0,588 \\
\hline \multicolumn{7}{|c|}{ Fluks $\mathrm{CO}_{2}\left(\mathrm{mg} / \mathrm{m}^{2} /\right.$ hari $)$} \\
\hline Pagi & 6.060 & 5.581 & 5.820 & 8.557 & 7.482 & 8.019 \\
\hline Siang & 6.149 & 5.515 & 5.832 & 8.607 & 6.514 & 7.561 \\
\hline Rata Rata & & & 5.826 & & & 7.790 \\
\hline
\end{tabular}

Hasil pengukuran emisi gas rumah kaca harian (GRK) pada di perkebunan kopi rakyat dengan sistem/konvensional menghasilkan nilai fluks $\mathrm{N}_{2} \mathrm{O}$ rata rata $0,5888 \mathrm{mg} / \mathrm{m}^{2} /$ hari dan fluks $\mathrm{CO}_{2} 7.790$ $\mathrm{mg} / \mathrm{m}^{2} /$ hari (Tabel 2). Hasil perhitungan emisi gas
$\mathrm{N}_{2} \mathrm{O}$ dari sistem konvensional sebesar 2,15 $\mathrm{kg} / \mathrm{ha} /$ tahun (Tabel 3) atau setara $641 \mathrm{~kg}$ CO2e/ha/tahun. Lahan yang ditanami tanaman kopi berumur 10 tahun menghasilkan emisi $\mathrm{N}_{2} \mathrm{O}$ sebesar $1,8 \mathrm{~kg} \mathrm{~N} / \mathrm{ha} /$ tahun (Verchot et al, 2006). Hergoualc'h 
et al.(2008), menambahkan faktor yang berpengaruh terhadap emisi $\mathrm{N}_{2} \mathrm{O}$ tidak hanya dari segi pemupukan nitrogen, tetapi faktor lingkungan dan teknis budidaya juga memberi pengaruh antara lain ketersediaan nutrisi dalam tanah, suhu tanah, kandungan air dalam tanah, manajemen persiapan lahan, dan kondisi iklim sekitar.

Hasil pengukuran emisi GRK pada pagi dan siang hari terdapat perbedaan. Perbedaan tersebut disebabkan perbedaan kondisi lingkungan (suhu dan kelembaban) antara padi dan siang hari. Pada pagi hari rata rata suhu pada lokasi organic lebih rendah dibanding lokasi konvensional. Suhu pada lokasi organik berkisar $15-26{ }^{\circ} \mathrm{C}$ sedangkan pada lokasi konvensional suhu berkisar 22-33 ${ }^{\circ} \mathrm{C}$. Pada siang hari suhu pada lokasi organik lebih tinggi dibandingkan pada lokasi konvensional. Pada lokasi organik berkisar $26-41^{\circ} \mathrm{C}$ sedangkan pada lokasi konvensional berkisar 21-28 ${ }^{\circ} \mathrm{C}$. Perbedaan suhu tersebut yang mungkin menjadi penyebab fluks pada lokasi organic lebih besar pada pagi hari sedangkan lokasi konvensional lebih besar pada siang hari.

Total emisi $\mathrm{CO}_{2}$ tahunan pada sistem konvensional sebesar 21,26 ton/ha/tahun sedangkan pada sistem organik sebesar 28,43 ton/ha/tahun (Tabel 3). Penggunaan pupuk organik dalam kegiatan budidaya di perkebunan kopi mempu mengurangi emisi $\mathrm{CO}_{2}$ sebesar 25,2 \%. Emisi $\mathrm{CO}_{2}$ dipengaruhi oleh proses biotik dan abiotik yang berhubungan dengan aktivitas di perakaran tanaman dan respirasi organisme (Berisso et al, 2013). Proses tersebut dipengaruhi oleh iklim mikro setempat. Pemberian bahan organik dalam bentuk matang siap di serap tanaman dapat mengurangi aktivitas mikroba yang berpengaruh terhadap respirasi mikroba. Respirasi mikroba berkaitan erat dengan suhu tanah, dimana suhu tanah berhubungan dengan fluks CO2 (Javed Iqbal et al, 2009).

Emisi GRK dari lahan perkebunan kopi di dominasi oleh gas $\mathrm{CO}_{2}$. Kontribusi gas $\mathrm{N}_{2} \mathrm{O}$ terhadap total keseluruhan emisi GRK hanya $3 \%$. Nilai tersebut diperoleh dengan mengkalikan emisi $\mathrm{N}_{2} \mathrm{O}$ dengan 298 dan di tambah dengan emisi $\mathrm{CO}_{2}$ (IPCC, 2006). Potensi pemanasan global/ Global Warming Potential (GWP) dari gas $\mathrm{N}_{2} \mathrm{O}$ dan $\mathrm{CO}_{2}$ yang di emisikan berkisar 21,8729,07 ton $\mathrm{CO}_{2} \mathrm{e} / \mathrm{ha} /$ tahun dari sistem budidaya yang diterapkan (Tabel 3). Nilai GWP tersebut lebih kecil dibandingkan perkebunan kopi rakyat di NTB. Perkebunan kopi rakyat di NTB menghasilkan GWP sebesar 47 ton CO2-e/ha/tahun (Pramono, Sadmaka, 2018). Noponen et al. (2013), menyatakan bahwa emisi GRK tertinggi diperoleh dari perlakuan konvensional dibandingkan perlakuan organik pada sistem budidaya kopi. Penggunaan pupuk organik dalam upaya mitigasi gas rumah kaca mampu menurunkan GWP sebesar $24.76 \%$.

Tabel 3. Emisi Gas Rumah Kaca (GRK) dan Global Warming Potential (GWP) dari dua sistem budidaya pada perkebunan kopi rakyat di NTT

\begin{tabular}{cccc}
\hline \hline \multirow{2}{*}{ Lokasi } & \multicolumn{2}{c}{ Emisi GRK/ GHG emission } & \multirow{2}{*}{ GWP (ton $\mathrm{CO}_{2} \mathrm{e} / \mathrm{ha} /$ tahun) } \\
\cline { 2 - 3 } & $\mathrm{N}_{2} \mathrm{O}(\mathrm{kg} / \mathrm{ha} /$ tahun $)$ & $\mathrm{CO}_{2}$ (ton/ha/tahun) & 21,87 \\
Mitigasi & 2,05 & 21,26 & 21,87 \\
\hline Konvensional & 2,15 & 28,43 & 29,07 \\
\hline \hline
\end{tabular}

Keterangan: GWP : $\left(298 \times\right.$ emisi $\left.\mathrm{N}_{2} \mathrm{O}\right)+$ emisi $\mathrm{CO}_{2}$

\subsection{Cadangan Karbon Dari Lahan Perkebunan Kopi Rakyat}

Perhitungan cadangan karbon merupakan salah satu alternatif dalam upaya kegiatan mitigasi di lahan perkebunan untuk mengurangi emisi GRK serta meningkatkan penyerapan $\mathrm{CO}_{2}$ melalui sekuestrasi karbon tanah dan tanaman. Cadangan karbon merupakan jumlah karbon yang tersimpan dari berbagai bagian. Pengukuran cadangan karbon di perkebunan kopi dilakukan dari biomassa tanaman/pohon serta tumbuhan bawah. Hasil perhitungan cadangan karbon dari lahan perkebunan kopi pada tumbuhan bawah di lokasi konvensional dan organik tersaji pada Tabel 4 dan Tabel 5. Hasil Perhitungan karbon biomassa tanaman/pohon dengan ukuran sampel plot 4 × 10 m tersaji pada Tabel 6 dan Tabel. 7.

Tabel 4. Berat kering tumbuhan bawah (understorey), seresah, dan ranting (dalam plot $1 \times 1 \mathrm{~m}$ ) di lokasi sistem konvensional.

\begin{tabular}{|c|c|c|c|c|c|c|c|}
\hline No & Vegetasi & $\begin{array}{c}\text { Berat } \\
\text { Basah (g) }\end{array}$ & $\begin{array}{c}\text { Sub Contoh Berat } \\
\text { Basah (g) }\end{array}$ & $\begin{array}{c}\text { Sub Contoh Berat } \\
\text { Kering (g) }\end{array}$ & $\begin{array}{c}\text { Total Berat } \\
\text { Kering }\left(\mathrm{g} / \mathrm{m}^{2}\right) \\
\end{array}$ & $\begin{array}{c}\text { C Tanaman } \\
(\%)\end{array}$ & $\begin{array}{c}\text { Cadangan C } \\
(\mathrm{kg} \mathrm{C} / \mathrm{ha})\end{array}$ \\
\hline 1 & Understorey 1 & 30 & 30 & 15 & 15 & 0,49 & 73,19 \\
\hline 2 & Understorey 2 & 170 & 170 & 85 & 85 & 0,38 & 321,43 \\
\hline 3 & Understorey 3 & 210 & 210 & 105 & 105 & 0,41 & 426,04 \\
\hline 4 & Seresah 1 & 210 & 210 & 105 & 105 & 0,48 & 507,05 \\
\hline 5 & Seresah 2 & 90 & 90 & 45 & 45 & 0,48 & 216,05 \\
\hline 6 & Seresah 3 & 20 & 20 & 10 & 10 & 0,52 & 52,09 \\
\hline 7 & Ranting 1 & 200 & 200 & 100 & 100 & 0,45 & 450,1 \\
\hline 8 & Ranting 2 & 80 & 80 & 40 & 40 & 0,46 & 183,8 \\
\hline 9 & Ranting 3 & 50 & 50 & 25 & 25 & 0,47 & 116,55 \\
\hline \multicolumn{5}{|c|}{ Total } & 530 & 4,13 & 2.346 \\
\hline
\end{tabular}


Tabel 5. Berat kering tumbuhan bawah (understorey), seresah, dan ranting (dalam plot $1 \times 1 \mathrm{~m}$ ) di lokasi sistem organik

\begin{tabular}{|c|c|c|c|c|c|c|c|}
\hline No. & Vegetasi & $\begin{array}{l}\text { Berat } \\
\text { Basah } \\
\end{array}$ & $\begin{array}{c}\text { Sub Contoh Berat } \\
\text { Basah (g) }\end{array}$ & $\begin{array}{c}\text { Sub Contoh Berat } \\
\text { Kering (g) }\end{array}$ & $\begin{array}{c}\text { Total Berat } \\
\text { Kering }\left(\mathrm{g} / \mathrm{m}^{2}\right) \\
\end{array}$ & $\begin{array}{c}\text { C Tanaman } \\
(\%)\end{array}$ & $\begin{array}{c}\text { Cadangan } \mathrm{C} \\
(\mathrm{kg} \mathrm{C} / \mathrm{ha})\end{array}$ \\
\hline 1 & Understorey 1 & 130 & 130 & 65 & 65 & 0,38 & 247,2 \\
\hline 2 & Understorey 2 & 110 & 110 & 55 & 55 & 0,40 & 222,3 \\
\hline 3 & Understorey 3 & 110 & 110 & 55 & 55 & 0,41 & 223,7 \\
\hline 4 & Seresah 1 & 20 & 20 & 10 & 10 & 0,50 & 50,1 \\
\hline 5 & Seresah 2 & 20 & 20 & 10 & 10 & 0,49 & 49,9 \\
\hline 6 & Seresah 3 & 10 & 10 & 5 & 5 & 0,52 & 26,0 \\
\hline 7 & Ranting 1 & 60 & 60 & 30 & 30 & 0,46 & 137,4 \\
\hline 8 & Ranting 2 & 60 & 60 & 30 & 30 & 0,46 & 136,9 \\
\hline 9 & Ranting 3 & 10 & 10 & 5 & 5 & 0,45 & 22,49 \\
\hline \multicolumn{5}{|c|}{ Total } & 265 & 4,08 & 1.116 \\
\hline
\end{tabular}

Tabel 6. Cadangan karbon pada biomasa tanaman/pohon (dalam plot berukuran $4 \mathrm{~m}$ x $10 \mathrm{~m}$ ) pada lokasi konvensional.

\begin{tabular}{|c|c|c|c|c|c|c|c|}
\hline No & Nama Pohon & $\begin{array}{l}\text { Keliling Pohon } \\
(\mathrm{cm})\end{array}$ & $\begin{array}{l}\text { Tinggi Pohon } \\
(\mathrm{cm})\end{array}$ & $\begin{array}{c}\text { Diameter } \\
\text { Pohon }(\mathrm{cm})\end{array}$ & $\begin{array}{l}\text { Berat Jenis tanaman } \\
(\rho)(\mathrm{g} / \mathrm{cm} 3)\end{array}$ & $\begin{array}{l}\text { Berat Kering } \\
\text { (Kg/pohon)/ }\end{array}$ & $\begin{array}{c}\text { C-Tanaman } \\
\text { (Kg C/Pohon) }\end{array}$ \\
\hline 1 & Pisang & 46 & 350 & 14,65 & & 7,816 & 3,595 \\
\hline 2 & Pisang & 47,5 & 380 & 15,13 & & 8,350 & 3,841 \\
\hline 3 & Ampupu & 25 & 170 & 7,96 & 0,89 & 22,461 & 10,332 \\
\hline 4 & Sengon & 183 & 257 & 58,28 & 0,55 & 2555,180 & 1175,383 \\
\hline 5 & Kopi & 10,5 & 310 & 3,34 & & 3,378 & 1,554 \\
\hline 6 & Kopi & 7,11 & 315 & 2,26 & & 1,513 & 0,696 \\
\hline 7 & Kopi & 14,5 & 170 & 4,62 & & 6,568 & 3,021 \\
\hline 8 & Kopi & 14,5 & 380 & 4,62 & & 6,568 & 3,021 \\
\hline 9 & Kopi & 15,5 & 410 & 4,94 & & 7,536 & 3,466 \\
\hline 10 & Kopi & 6,11 & 315 & 1,95 & & 1,107 & 0,509 \\
\hline 11 & Kopi & 13,5 & 170 & 4,30 & & 5,669 & 2,608 \\
\hline 12 & Kopi & 18,5 & 600 & 5,89 & & 10,849 & 4,991 \\
\hline 13 & Kopi & 15,2 & 180 & 4,84 & & 7,238 & 3,330 \\
\hline 14 & Kopi & 16,2 & 460 & 5,16 & & 8,253 & 3,797 \\
\hline 15 & Kopi & 13,5 & 570 & 4,30 & & 5,669 & 2,608 \\
\hline 16 & Kopi & 14 & 530 & 4,46 & & 6,110 & 2,811 \\
\hline 17 & Kopi & 15,5 & 550 & 4,94 & & 7,536 & 3,466 \\
\hline 18 & Kopi & 15,5 & 610 & 4,94 & & 7,536 & 3,466 \\
\hline 19 & Kopi & 22,5 & 510 & 7,17 & & 16,238 & 7,469 \\
\hline 20 & Kopi & 16 & 460 & 5,10 & & 8,045 & 3,701 \\
\hline 21 & Kopi & 11 & 140 & 3,50 & & 3,718 & 1,710 \\
\hline 22 & Kopi & 11,5 & 470 & 3,66 & & 4,074 & 1,874 \\
\hline 23 & Kopi & 12,5 & 520 & 3,98 & & 4,838 & 2,225 \\
\hline 24 & Kopi & 18,5 & 460 & 5,89 & & 10,849 & 4,991 \\
\hline 25 & Kopi & 19 & 2010 & 6,05 & & 11,462 & 5,273 \\
\hline 26 & Kopi & 4,1 & 230 & 1,31 & & 0,487 & 0,224 \\
\hline 27 & Kopi & 10,5 & 140 & 3,34 & & 3,378 & 1,554 \\
\hline 28 & Kopi & 17,5 & 160 & 5,57 & & 9,676 & 4,451 \\
\hline 29 & Kopi & 14,5 & 120 & 4,62 & & 6,568 & 3,021 \\
\hline 30 & Kopi & 19 & 330 & 6,05 & & 11,462 & 5,273 \\
\hline 31 & Kopi & 11,5 & 420 & 3,66 & & 4,074 & 1,874 \\
\hline 32 & Kopi & 16 & 165 & 5,10 & & 8,045 & 3,701 \\
\hline 33 & Kopi & 18 & 320 & 5,73 & & 10,254 & 4,717 \\
\hline 34 & Kopi & 14 & 330 & 4,46 & & 6,110 & 2,811 \\
\hline 35 & Kopi & 14 & 270 & 4,46 & & 6,110 & 2,811 \\
\hline 36 & Kopi & 18,5 & 180 & 5,89 & & 10,849 & 4,991 \\
\hline 37 & Kopi & 21 & 500 & 6,69 & & 14,086 & 6,480 \\
\hline 38 & Kopi & 16 & 210 & 5,10 & & 8,045 & 3,701 \\
\hline 39 & Kopi & 26 & 3 & 8,28 & & 21,871 & 10,061 \\
\hline 40 & Kopi & 14 & 175 & 4,46 & & 6,110 & 2,811 \\
\hline 41 & Kopi & 15 & 140 & 4,78 & & 7,043 & 3,240 \\
\hline 42 & Kopi & 14 & 135 & 4,46 & & 6,110 & 2,811 \\
\hline 43 & Kopi & 16 & 410 & 5,10 & & 8,045 & 3,701 \\
\hline 44 & Kopi & 15,5 & 165 & 4,94 & & 7,536 & 3,466 \\
\hline \multicolumn{7}{|c|}{ Total (kg C/Pohon) } & 1331,435 \\
\hline \multicolumn{7}{|c|}{ Total (kg C /ha) } & 332.858 \\
\hline
\end{tabular}

Keterangan : Total C (kg/ha) : Total C (kg/pohon) * $10.000 \mathrm{~m}^{2} /$ luas pengambilan sampel $\left(\mathrm{m}^{2}\right)$

Tabel 7. Cadangan karbon pada biomasa tanaman/pohon (dalam plot berukuran $4 \mathrm{~m}$ x $10 \mathrm{~m}$ ) Pada Lokasi Sistem Organik 


\begin{tabular}{|c|c|c|c|c|c|c|c|}
\hline No & Nama Pohon & $\begin{array}{l}\text { Keliling Pohon } \\
(\mathrm{cm})\end{array}$ & $\begin{array}{l}\text { Tinggi Pohon } \\
\text { (cm) }\end{array}$ & $\begin{array}{c}\text { Diameter } \\
\text { Pohon }(\mathrm{cm}) \\
\end{array}$ & $\begin{array}{c}\text { Berat Jenis tanaman } \\
(\rho)(\mathrm{g} / \mathrm{cm} 3)\end{array}$ & $\begin{array}{l}\text { Berat Kering } \\
\text { (Kg/pohon) }\end{array}$ & $\begin{array}{c}\text { C-Tanaman } \\
\text { (Kg C/Pohon) }\end{array}$ \\
\hline 1 & Sengon & 104 & 250 & 33,121 & 0,55 & 546,99 & 251,62 \\
\hline 2 & Sengon & 77 & 200 & 24,522 & 0,55 & 233,57 & 107,44 \\
\hline 3 & Kopi & 9 & 150 & 2,866 & & 2,459 & 1,131 \\
\hline 4 & Kopi & 6,2 & 130 & 1,975 & & 1,141 & 0,525 \\
\hline 5 & Kopi & 12 & 150 & 3,822 & & 4,448 & 2,046 \\
\hline 6 & Kopi & 12 & 130 & 3,822 & & 4,448 & 2,046 \\
\hline 7 & Kopi & 13 & 130 & 4,140 & & 5,245 & 2,413 \\
\hline 8 & Kopi & 6,5 & 120 & 2,070 & & 1,258 & 0,579 \\
\hline 9 & Kopi & 16 & 160 & 5,096 & & 8,045 & 3,701 \\
\hline 10 & Kopi & 16 & 130 & 5,096 & & 8,045 & 3,701 \\
\hline 11 & Kopi & 14 & 130 & 4,459 & & 6,110 & 2,811 \\
\hline 12 & Kopi & 10 & 140 & 3,185 & & 3,055 & 1,405 \\
\hline 13 & Kopi & 6,5 & 115 & 2,070 & & 1,258 & 0,579 \\
\hline 14 & Kopi & 5,7 & 120 & 1,815 & & 0,960 & 0,441 \\
\hline 15 & Kopi & 3,2 & 130 & 1,019 & & 0,292 & 0,134 \\
\hline 16 & Kopi & 5,1 & 160 & 1,624 & & 0,763 & 0,351 \\
\hline 17 & Kopi & 4 & 140 & 1,274 & & 0,463 & 0,213 \\
\hline 18 & Kopi & 17,5 & 130 & 5,573 & & 9,676 & 4,451 \\
\hline 19 & Kopi & 12 & 120 & 3,822 & & 4,448 & 2,046 \\
\hline 20 & Kopi & 10,1 & 150 & 3,217 & & 3,118 & 1,434 \\
\hline 21 & Kopi & 16 & 130 & 5,096 & & 8,045 & 3,701 \\
\hline 22 & Kopi & 18,5 & 130 & 5,892 & & 10,849 & 4,991 \\
\hline 23 & Kopi & 18 & 130 & 5,732 & & 10,254 & 4,717 \\
\hline 24 & Kopi & 4 & 130 & 1,274 & & 0,463 & 0,213 \\
\hline 25 & Kopi & 6,5 & 170 & 2,070 & & 1,258 & 0,579 \\
\hline 26 & Kopi & 7 & 145 & 2,229 & & 1,465 & 0,674 \\
\hline 27 & Kopi & 5,3 & 170 & 1,688 & & 0,826 & 0,380 \\
\hline 28 & Kopi & 3,6 & 230 & 1,146 & & 0,372 & 0,171 \\
\hline 29 & Kopi & 5,5 & 140 & 1,752 & & 0,892 & 0,410 \\
\hline 30 & Kopi & 8 & 132 & 2,548 & & 1,929 & 0,887 \\
\hline 31 & Kopi & 8 & 165 & 2,548 & & 1,929 & 0,887 \\
\hline 32 & Kopi & 8 & 115 & 2,548 & & 1,929 & 0,887 \\
\hline 33 & Kopi & 9,5 & 150 & 3,025 & & 2,749 & 1,264 \\
\hline 34 & Kopi & 8 & 150 & 2,548 & & 1,929 & 0,887 \\
\hline 35 & Kopi & 6,5 & 150 & 2,070 & & 1,258 & 0,579 \\
\hline 36 & Kopi & 17,5 & 160 & 5,573 & & 9,676 & 4,451 \\
\hline 37 & Kopi & 12 & 180 & 3,822 & & 4,448 & 2,046 \\
\hline \multicolumn{7}{|c|}{ Total (kg C/ Pohon) } & 416,79 \\
\hline \multicolumn{7}{|c|}{ Total (kg C/ha) } & 104.198 \\
\hline
\end{tabular}

Keterangan : Total C (kg/ha) : Total C (kg/pohon) * $10.000 \mathrm{~m}^{2} /$ luas pengambilan sampel $\left(\mathrm{m}^{2}\right)$

Tabel 8. Cadangan Karbon, Global Warming Potential (GWP) dan Serapan Karbon dari 2 sistem budidaya pada perkebunan kopi rakyat di NTT

\begin{tabular}{|c|c|c|c|c|c|}
\hline \multirow{2}{*}{ Lokasi } & \multicolumn{2}{|c|}{ Cadangan Carbon (ton C/ha) } & \multirow{2}{*}{$\begin{array}{l}\text { Total Cadangan Karbon (ton } \\
\text { CO2e/ ha) }\end{array}$} & \multirow{2}{*}{$\begin{array}{c}\text { GWP } \\
\text { (ton } \mathrm{CO} 2 \mathrm{e} / \mathrm{ha} / \text { thn) }\end{array}$} & \multirow{2}{*}{$\begin{array}{l}\text { Serapan Karbon } \\
\text { (ton } \mathrm{CO} 2 \mathrm{e} / \mathrm{ha} \text { ) }\end{array}$} \\
\hline & Biomassa Tanaman & Understorey & & & \\
\hline Organik & 104,20 & 1,116 & 382,06 & 21,87 & 360,19 \\
\hline Konvensional & 332,86 & 2,346 & 1220,49 & 29,07 & 1191,42 \\
\hline
\end{tabular}

Keterangan: Total Cadangan Karbon : Total C/ha x 44/12 CO2e/ ha

Cadangan karbon dari tumbuhan bawah (understorey), seresah dan ranting pada lokasi sistem konvensional sebesar $2.346 \mathrm{~kg} \mathrm{C} / \mathrm{ha}(2,3 \mathrm{Mg} \mathrm{C} / \mathrm{ha})$ (Tabel 4), dan pada lokasi sistem organik sebesar $1.116 \mathrm{~kg} \mathrm{C} / \mathrm{ha}(1,1 \mathrm{Mg} \mathrm{C} / \mathrm{ha})$ (Tabel 5). Hasil perhitungan tersebut sesuai dengan cadangan karbon yang dihasilkan seresah pada perkebunan kopi rakyat di kecamatan Sumberbaru dan Silo Provinsi Jawa Timur yang berkisar 1,03-2,95 Mg/ha (Wibawa et al, 2010). Cadangan karbon juga dilakukan pada biomassa tanaman atau pohon pada lokasi konvensioanl sebesar $332.858 \mathrm{~kg} \mathrm{C} / \mathrm{ha}$ (332,86 Mg C/ha) (Tabel 6). Pada lokasi organik cadangan karbon dari biomassa tanaman/pohon sebesar $104.198 \mathrm{~kg}$ C/ha (104,2 Mg C/ha) (Tabel 7). Simpanan karbon pada kopi Arabika sebesar 22,02 Mg/ha Cadangan 103 karbon pada lokasi dengan sistem konvensional lebih besar dibandingkan pada lokasi dengan sistem organik. Cadangan karbon pada perkebunan kopi dipengaruhi oleh tipe pengelolaan kebun termasuk pemilihan jenis dan kerapatan pohon penaung, umur kebun, pemupukan dan penyiangan (Hairiah dan Rahayu, 2010).

Cadangan karbon pada kegiatan budidaya tanaman kopi di lokasi penelitian sebesar 382,06 ton $\mathrm{CO}_{2} \mathrm{e}$ / ha pada lokasi organik serta 1220,49 ton $\mathrm{CO}_{2} \mathrm{e} /$ ha pada lokasi konvensional (Tabel 8).Pada lokasi konvensional memiliki umur tanaman 15 tahun sedangkan pada lokasi organik yang memiliki umur tanaman 6 tahun. Umur tanaman mempunyai pengaruh terhadap diameter tanaman yang akan berpengaruh terhadap berat kering biomassa 
tanaman. Cadangan karbon pada agroforestri kopi tua sebesar 63,69, sedangkan cadangan karbon pada agroforestri muda sebesqar 27,92 ton C/ha (Rochmayanto et al, 2014). Pramono dan Sadmaka (2018) menambahkan perkebunan kopi rakyat yang berumur kurang dari 10 tahun menyimpan cadangan karbon sebesar 91,4 ton $\mathrm{C} / \mathrm{ha}$.

Beragamnya jenis tanaman yang terdapat pada lokasi penelitian menunjukkan petani sudah menerapkan budidaya secara agroforestri. Terdapatnya tanaman tahunan sebagai penaung juga memberi kontribusi terhadap cadangan karbon yang dihasilkan dari suatu lahan. Kontribusi tanaman penaung kopi mencapai $83 \%$ dari total cadangan karbon (bagian atas tanah) pada sistem agroforestri multistrata dan sekitar $76 \%$ untuk agroforestri sederhana, sedangkan dari pohon kopi sekitar 1724\% (Hairiah dan Rahayu, 2010). Beberapa wilayah di Indonesia, cadangan karbon pada agroforestri multistrata berbasis kopi sebesar $43 \mathrm{Mg} / \mathrm{h}$, agroforestri sederhana (naungan tunggal) berbasis kopi pada lahan milik masyarakat rata-rata $23 \mathrm{Mg} / \mathrm{ha}$ dan $38 \mathrm{Mg} /$ ha diperoleh pada lahan percobaan. Sedang cadangan karbon lahan kopi monokultur sekitar $13 \mathrm{Mg} / \mathrm{ha}$. Laju pertumbuhan cadangan karbon pada agroforestri multistrata berbasis kopi adalah $0.9-1.86 \mathrm{Mg} / \mathrm{ha} / \mathrm{th}$ dan agroforestri sederhana (milik masyarakat) rata-rata 0.6 - 0.97 $\mathrm{Mg} / \mathrm{ha} / \mathrm{th}$ dan $2.8 \mathrm{Mg} / \mathrm{ha} /$ th di kebun percobaan. Sedang pada lahan kopi monokultur hanya sekitar 0.5 $\mathrm{Mg} / \mathrm{ha}$. Dengan demikian time averaged C stock agroforestri kopi diestimasi sekitar $41 \mathrm{Mg} / \mathrm{ha}$, sedang lahan kopi monokultur hanya sekitar $12.5 \mathrm{Mg} / \mathrm{ha}$ (Hairiah dan Rahayu, 2010).

Kemampuan tanaman dalam menyerap karbon menunjukkan bahwa tanaman tersebut efektif dan aktif dalam melakukan kegiatan fotosintesis. Serapan karbon diperoleh dari pengurangan emisi GRK dengan cadangan karbon dari suatu lahan. Perkebunan kopi rakyat dengan sistem organik menyerap karbon sebesar 360,19 ton $\mathrm{CO}_{2} \mathrm{e} / \mathrm{ha}$, sedangkan pada perkebunan kopi rakyat dengan sistem konvensional menyerap karbon sebesar 1191,42 ton $\mathrm{CO}_{2} \mathrm{e}$ / ha (Tabel 8). Terdapatnya tanaman penaung berjenis tanaman tahunan (sengon, ampupu dan albesia) pada lokasi sistem organik dan konvensional mampu meningkatkan serapan karbon pada suatu lahan. Serapan karbon dari suatu lokasi bergantung jenis tanaman naungan dan pengelolaan pohon untuk menghasilkan sekuestrasi karbon yang tinggi. Serapan karbon pada lokasi yang mempunyai naungan tanaman tahunan akan menghasilkan serapan karbon yang lebih tinggi (Hergoualc'h et al. 2008: Noponen et al., 2013). Hairiah dan Rahayu (2010) menambahkan biomassa pohon penaung kopi menyumbang $40-70 \%$ total cadangan karbon pada lahan agroforestry multistrata. Wibawa et al (2010) menambahkan sistem agroforestri pada tanaman kopi menambah serapan karbon mencapai $19 \mathrm{Mg} / \mathrm{ha}$.

Perhitungan jejak karbon pada suatu lahan berguna unruk mengetahui pakah cara budidaya yang diterapkan meningkatkan atau mengurangi karbon. Jejak karbon pada tingkat produksi kopi untuk $1 \mathrm{~kg}$ kopi segar 0,05 $\mathrm{kg} \mathrm{CO}_{2}$-e, 0,24 $\mathrm{kg} \mathrm{CO}_{2}$-e 0,54 kg CO 2 -e untuk kategori rendah, sedang dan tinggi (Maina et al, 2015). Jejak karbon untuk menghasilkan $1 \mathrm{~kg}$ kopi berkisar 1,77 - 3,05 kg CO 2 -e (Killian et al, 2013). Hasil penelitian Noponen et al (2013) menyatakan jejak karbon pada kegiatan budidaya konvensional berkisar 0,26-0,67 $\mathrm{kg} \mathrm{CO}_{2} \mathrm{e}$ dan pada kegiatan budidaya organik berkisar 0,12-0,52 kg $\mathrm{CO}_{2} \mathrm{e}$. Kegiatan budidaya organik menghasilkan jejak karbon yang lebih rendah.

Pengelolaan perkebunan kopi dengan menggunakan sistem organik mampu menurunkan emisi GRK. Penggunaan bahan organik mampu mengurangi emisi $\mathrm{N}_{2} \mathrm{O}$ yang dihasilkan suatu lahan. Terdapatnya beragam jenis tanaman penaung pada budidaya organic maupun konvensional menunjukkan sistem perkebunan rakyat di NTT dilaksanakan dengan sistem agroforestri. Pengelolaan tanaman kopi dengan sistem agroforestri/ ada tanaman penaung mampu meningkatkan cadangan karbon dan serapan karbon. Serapan karbon pada lokasi penelitian berkisar 98-325 ton C/ha. Serapan karbon tersebut lebih besar dibanding dengan serapan karbon di perkebunan kopi rakyat di NTB. Besarnya cadangan karbon 91,4 ton C/ha (Pramono dan Sadmaka, 2018). Pengelolaan perkebunan secara organik dengan tanaman tahunan sebagai penaung (Agrogorestri) merupakan kegiatan ramah lingkungan sebagai upaya mitigasi gas rumah kaca.

\section{Kesimpulan}

Berdasarkan hasil penelitian dapat disimpulkan bawah penerapan budidaya dengan sistem organik pada perkebunan kopi mampu menurunkan GWP sebesar 24,77 \% dibandingkan pada lokasi konvensional. Sistem budidaya perkebunan kopi rakyat di NTT sudah dilaksanakan dengan sistem agroforestri. Keragaman jenis tanaman penaung, umur tanaman yang lebih tua dan sistem budidaya menghasilkan sistem budidaya konvensional menghasilkan menghasilkan cadangan karbon dan serapan karbon yang lebih besar dibandingkan dengan sistem organik

Penggunaan bahan organik serta tanaman penaung dengan sistem agroforestri pada budidaya kopi rakyat perlu ditingkat karena mampu menurunkan emisi gas rumak kaca dan menaikkan cadangan karbon. Hasil penelitian ini dapat digunakan sebagai data untuk penyuluhan kepada petani untuk 
mau mengunakan bahan organik dan sistem budiaya agroforestri pada lahan perkebunan kopi milik petani sebagai upaya untuk mitigasi terhadap perubahan iklim.

\section{DAFTAR PUSTAKA}

Bale J, Masters GJ, Hodkinson ID, Awmack C, et al. (2002) Herbivory in global climate change research: direct effects of rising temperature on insect herbivores.Glob Change Biol 8: 1-16.

Berisso FE, P Schjønning, T Keller, M Lamandé, A Simojoki, BV Iversen, L Alakukku \& J Forkman (2013). Gas transport and subsoil pore characteristics: anisotropy and long-term effects of compaction. Geoderma 195196, 184-191.

Bisang, B.W., F. Jansen., K. Linne., T. Nguyen., H. Wals. 2016. Climate Change And Vietnamese Coffee Production (Manual On Climate Change Adaptation And Mitigation In The Coffee Sector For Local Trainersand Coffee Farmers). Implementing Agent Coffe Climate Care (C3) : 46p

Cerdan, C.R., M.C. Rebolledo., G.Soto., B. Rapidel., and F.L Sinclair. 2012. Lokal Knowledge of Impact of Tree Cover on Ecosystem Services in Smallholder Coffe Production System. Journal Agricultural System 111: 119-130 p.

Fain, S.J., M. Quinones., L. Nora., A. Berroz., K. Isabel., P. Ramos., and W.A. Gould. 2017. Climate Change and Coffe: Assessing Vulnerability by Modelling Future Climate Suitability in the Caribbean Island of Puerto Rico. Climatic Change: 12p. DOI 10.1007/s10584-0171949-5

Graham RF, SE Wortman \& CM Pittelkow (2017). Comparison of organic and integrated nutrient management strategies for reducing soil N2O emissions. Sustainability 9, 510; doi:10.3390/su9040510www.mdpi.com/journal/sus tainability.

Groenen, Danielle. 2018. The Effect of Climate Change on the Pest and Desease of Coffe Crops in Mesoamerica. Journal of Climatology \& Weather Forecasting 6(3): 5p. DOI: $10.4172 / 2332-2594.1000239$

Hairiah K \& S Rahayu (2007). Pengukuran 'karbon tersimpan' di berbagai macam penggunaan lahan. Bogor. World. Agroforestry Centre - ICRAF, SEA Regional Office, University of Brawijaya, Unibraw, Indonesia. 77 p. 979-3198-35-4.

Hairiah, K dan S. Rahayu. 2010. Mitigasi Perubahan Iklim: Agroforestry kopi untuk mempertahankan cadangan karbon lanskap. Simposium Kopi: 31 hal.

Hairiah, K, S, Dewi, F, Agus, S, Velarde, A, Ekadinata, S, Rahayu, and M, van Noordwijk, 2011, Measuring Carbon Stock Across Land Use Systems: A manual, World Agroforestry Centre, ICRAFSE Asia Regional Office, Bogor, 154 pp.

Houghton, R, A, J, D, Unruh, and P, A, Lefebvre (1993), Current land cover in the tropics and its potential for sequestering carbon, Global Biogeochem, Cycles, 7: 305-320.

Hergoualc'h, K., 2008. Soil Greenhouse Gases Emissions and Carbon Storage in Coffee Plantations on Andosols in
Tropical Climate. CATIE/CIRAD Costa Rica/ Montpellier, PhD Thesis, $229 \mathrm{p}$.

IAEA-International Atomic Energy Agency 1992. 1992. "Manual on Measurement of Methane." Manual on Measurement ofMethane and Nitrous Oxide Emission from

Agricultural.52.https://inis.iaea.org/collection/NCLC ollectionStore/_Public/24/019/24019160.pdf

Intergovernmental Panel on Climate Change (2000), Land Use, Land-Use Change, and Forestry: 2000 Special Report of the Intergovernmental Panel on Climate Change, edited by R, T, Watson et al,, Cambridge Univ, Press, New York.

IPCC (Intergovernmental Panel on Climate Change). 2014. Climate change 2014: Impacts, adaptation, and vulnerability. Part a: Global and sectoral aspects. Contribution of working group II to the Fifth Assessment Report of the Intergovernmental Panel on Climate Change. Technical Report.

IPCC (Intergovernmental Panel on Climate Change). 2006. IPCC Guidelines for National Greenhouse Gas Inventories. Prepared by The National Greenhouse Gas Inventories Programme, In Eggleston H.S., Buendia, L., Miwa, K., Ngara, T. \& Tanabe, K. (Eds.). IPCC National Greenhouse Gas Inventory Programme, Published by IGES

Jaramillo, J., E. Muchugu., F.E. Vega., A. Davis., C. Borgemeister., A.C. Olaye. 2011. Some Like It Hot: The Influence and Implication of Climate Change on Coffe Berry Borer (Hypothenemus hampei) and Coffe Production in East Africa. PLoS ONE 6 (9) : 14p

Jaramillo, SE., Osario A, dan Coreea GA. 2017. Emission and Fixation of greenhouse gases in potential specialty coffee production zones in Antiquia-Colombia. Rev.Fac.Nac.Agron 70(3): 8341-8349p

Javed, I., R.Hu., S. Lin, R. Hatano, M.Feng , L. Lu, B. Ahamadoau, and L. Du. 2009. $\mathrm{CO}_{2}$ emission in a subtropical red paddy soil (ultisol) as affect by straw and N-Fertilizer application : A case study in SOuthertn China. Agricultural, Ecosytem and Environment 131 : 292-302.

Kementan (Kementerian Pertanian). 2015. Rencana Strategis Kementerian Pertanian 2015-2019. Sekretariat Jenderal, Kemenratiena Pertanian. 339 hlm.

Kilian, B., L. Rivena., M. Soto and D. Navichoc. 2013. Carbon footprint across the coffe supplay chain: the case of Costa Rican coffee. Journal of Agricultural Science and Technologi B (3): 151-170p.

Maina, JJ., UN Mutwiwa., GM Kituu and M. Githiru. 2015. Evaluatioan of greenhouse gas emission along teh small-holder coffe supply chain in Kenya. Journal of Sustainable Research in Enginering 2(4): 111-120p.

Minamikawa, K., T.Tokida., S. Sudo., A. Padre., K. Yagi., P. Setyanto., TD Hoa., A Chidthaisong., EB Sibayan., Y Takata., dan T Yamaguchi. Guidelines for Measuring $\mathrm{CH}_{4}$ and $\mathrm{N}_{2} \mathrm{O}$ Emissions from Rice Paddies by a Manually Operated Closed Chamber Methode (version1). National Institute for Agro Environmental Science. Japan. 80p.

Noponen, M.R.A., J.P. Haggar., G. E. Jones., and J. R. Healey. 2013. Intensification of Coffe System Can Increase The 
Effectiveness of REDD Mechanisms. Agricultural System $119: 1-9 p$

Peng S, S Piao, T Wang, T Sun \& Shen Z (2009). Temperature sensitivity of soil respiration in different ecosystems in China. Soil Biol Biochem 41(5): 1008-1014p.

Pramono, A dan Sadmaka. 2018. Emisi Gas Rumah Kaca, Cadangan Karbon, serta Strategi Adaptasi dan Mitigasi pada Perkebunan Kopi Rakyat di Nusa Tenggara Barat. Menara Perkebunan 86(2):62-71.

Prasetyo, SB., N. Aini dan D. Maghfoer. 2017. Dampak Perubahan Iklim terhadap Produktivitas Kopi Robusta di Kabupaten Malang. Jurnal produksi Tanaman 5(5): 805-811.

Pusdatin. 2017. Statistik Pertanian, Kementrian Pertanian, 408 hal

Rachawat, T., Chiarakorn, S., Chidthaisong., A. 2015. Greenhouse gas Emission of Robusta Coffe Plantation in Thailand. The Asian Conference on Sustainability, Energy \& the Environment 2015 Official Conference Proceedings. $8 \mathrm{p}$

Rochmayanto, Y., A. Wibowo., M. Lugina., T. Butarbutar., RM. Mulyadin., dan D. Wicaksono. 2014. Cadangan karbon pada berbagai tipe hutan dan jenis tanaman di Indonesia (Seri 2). Kanisius. Yogyakarta. 108 hal.

Sevenster, M and J Verhagen. 2010. GHG Emission of green coffe production: Toward standart metodologi for carbon footprinting. CE Delft. $47 \mathrm{p}$.

Syakir, M dan E. Surmaini. 2017. Perubahan iklim dalam konteks system produksi dan pengembangan kopi di Indonesia. Jurnal Litbang Pertanian 36(2): 77-90.

United Nations Development Programme (UNDP). 2005. Adaptation Policy Framework for Climate Change.

Verchot, L,V, L, Hutabarat,, K, Hairiah, and M, Van Noordwijk, 2006, Nitrogen Availability and Soil N2O Emission Following Conversion of Forest to Coffe in Southern Sumatra, Global Biogeochemical Cycle 20, GB4008

Wibawa, A., F. Yuliasmara dan R. Erwiyono. 2010. Estimasi Cadangan Karbon pada Perkebunan Kopi di Jawa Timur. Pelita Perkebunan 26: 1-11.

Widayat, HP., A. Anhar., dan A. Baihaqi. 2015. Dampak Perubahan iklim terhadap Produksi, Kualitas Hasil serta Pendapatan Petani Kopi Arabika di Aceh Tengah. Agrisep 16(2):8-16 